Discussion Paper No. 09-004

\title{
Choosing from the Reform Menu Card - Individual Determinants of Labour Market Policy Preferences
}

Friedrich Heinemann, Ivo Bischoff, and Tanja Hennighausen

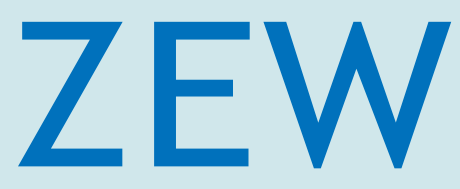

Zentrum für Europäische Wirtschaftsforschung $\mathrm{GmbH}$

Centre for European

Economic Research 
Discussion Paper No. 09-004

\title{
Choosing from the Reform Menu Card - Individual Determinants of Labour Market Policy Preferences
}

\author{
Friedrich Heinemann, Ivo Bischoff, \\ and Tanja Hennighausen
}

Download this ZEW Discussion Paper from our ftp server:

ftp://ftp.zew.de/pub/zew-docs/dp/dp09004.pdf

Die Discussion Papers dienen einer möglichst schnellen Verbreitung von neueren Forschungsarbeiten des ZEW. Die Beiträge liegen in alleiniger Verantwortung der Autoren und stellen nicht notwendigerweise die Meinung des ZEW dar.

Discussion Papers are intended to make results of ZEW research promptly available to other economists in order to encourage discussion and suggestions for revisions. The authors are solely responsible for the contents which do not necessarily represent the opinion of the ZEW. 


\section{Non-technical summary}

In many industrialised countries the demographic chance makes a better use of the labour force highly desirable. However, attempts to enact market orientated labour market reforms are regularly confronted with significant political resistance. This paper aims to contribute to a better understanding of the drivers of labour market reform acceptance at the individual level in Germany. Based on our theoretical considerations, we propose an analytical framework distinguishing between self-interest, information, fairness judgements and economic beliefs as well as other individual factors (e.g. socialisation in the former German Democratic Republic).

To test this framework empirically we use data from the representative German General Social Survey (ALLBUS) for the years 2000 and 2006. Next to information about the respondents' assessment of several market-oriented reform policies (e.g. benefit cuts, longer working years, cutting subsidies to declining industries, phasing out employment programmes or a liberalisation of employment protection), this survey offers data on individual fairness assessment as well as objective data on the respondents' socio economic characteristics.

The results indicate that self-interest (e.g. related to the respondents' income or employment status) is a major determinant for individual assessment of labour market reforms. Nevertheless, self-interest is not the full story behind the strong resistance against labour market reforms. The individuals' labour market policy preferences are also influenced by their informative situation, by their beliefs on the sources of economic success or the function of the democratic system. In addition, we found Eastern Germans to be more sceptical of liberal labour market reforms than their western fellow citizens. Our findings are relevant for a successfully selling of market-oriented labour-market reforms: It is not sufficient to point to the individual advantages of a reform, other fairness-oriented sources of reform resistance need to be addressed as well. 


\section{Zusammenfassung}

In vielen Industrieländern ist zwar angesichts des demografischen Wandels eine bessere Nutzung des Arbeitskräftepotenzials wünschenswert, marktorientierte Arbeitsmarktreformen treffen jedoch regelmäßig auf deutlichen politischen Widerstand. Die vorliegende Arbeit soll zu einem besseren Verständnis der Akzeptanz von Arbeitsmarktreformen auf der individuellen Ebene in Deutschland beitragen. Theoretische Überlegungen legen eine Unterscheidung zwischen Eigeninteressen, Informationsstand, individuellen Gerechtigkeitsurteilen und Einschätzungen bezüglich der Ursachen für wirtschaftlichen Erfolg sowie anderen individuellen Faktoren (z. B. Sozialisierung in der ehemaligen DDR) nahe.

Die empirischen Analysen basieren auf repräsentativen Umfragedaten für Deutschland, die im Rahmen der Allgemeinen Bevölkerungsumfrage der Sozialwissenschaften (ALLBUS) in den Jahren 2000 und 2006 erhoben wurden. Neben Informationen über die Einschätzung diverser marktorientierter Reformmaßnahmen durch die Teilnehmer (z. B. Kürzung von Sozialleistungen, Verlängerung der Lebensarbeitszeit, Kürzung von Subventionen für schwache Industrien, Abschaffung von Beschäftigungsprogrammen oder Liberalisierung des Kündigungsschutzes) sind auch eine Vielzahl weiterer individueller Werturteile und Einschätzungen sowie objektive Daten zur sozioökonomischen Lage der Befragten enthalten.

Die Ergebnisse unserer empirischen Analyse zeigen, dass Eigeninteressen zwar die individuelle Beurteilung von Arbeitsmarktreformen maßgeblich beeinflussen, aber den starken Widerstand gegen diese nicht vollständig erklären können. Vielmehr beeinflussen auch der Informationsstand, die Einschätzungen zur individuellen Eigenverantwortlichkeit und der Funktionsfähigkeit des demokratischen Systems die individuellen Präferenzen für Arbeitsmarktpolitik. Darüber hinaus stehen ostdeutsche Bürger Reformen, die eine stärkere Liberalisierung der Arbeitsmärkte zum Ziel haben, skeptischer gegenüber als ihre westdeutschen Mitbürger. Unsere Erkenntnisse könnten unter anderem für die erfolgreiche Präsentation von marktorientierten Arbeitsmarktreformen von Bedeutung sein: Möglicherweise reicht es nicht aus, die individuellen Vorteile durch die Reform zu betonen, andere fairness-orientierte Ursachen für Reformwiderstand müssen ebenso berücksichtigt werden. 


\title{
Choosing from the Reform Menu Card - \\ Individual Determinants of Labour Market Policy Preferences
}

\author{
Friedrich Heinemann $^{\mathrm{a} / *}$, Ivo Bischoff ${ }^{\mathrm{b}}$, Tanja Hennighausen ${ }^{\mathrm{c}}$ \\ a ZEW Mannheim, e-mail: heinemann@zew.de

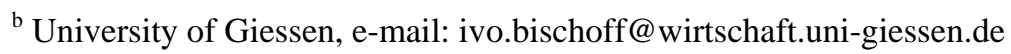 \\ c ZEW Mannheim, e-mail: hennighausen@zew.de
}

January 2009

\begin{abstract}
Keywords: labour market reform, economic beliefs, fairness preferences, ALLBUS
JEL-Classification: J48, D63, C42, A13
\end{abstract}

\begin{abstract}
This contribution empirically explores the drivers of labour market reform acceptance for the individual level in Germany. For that purpose we make use of the representative German General Social Survey (ALLBUS). This survey offers data to which extent individuals support benefit cuts, longer working years, cutting subsidies to declining industries, phasing out of employment programmes or a liberalisation of employment protection. Our theoretical considerations suggest that self-interest, information, fairness judgements, economic beliefs and other individual factors such as socialisation under the communist regime in the former German Democratic Republic drive individual reform preferences. Our empirical results support this notion: While we find self-interest to be an important driving force, our results show that a number of factors well beyond the narrow scope of self-interest strongly shape individual reform preferences.
\end{abstract}

*Corresponding author:

Friedrich Heinemann

Centre for European Economic Research (ZEW)

L 7,1

68161 Mannheim

Germany

Phone +49 6211235149

Fax +49621 1235223

Email heinemann@zew.de 


\section{Introduction}

Highly regulated labour markets remain a challenge for industrial countries like Germany, France or Italy. While demographic change makes a better use of the labour force highly desirable, existing labour market institutions still entail obstacles and disincentives for employment. At the same time, attempts to enact market oriented labour market reforms are regularly confronted with significant political resistance. The German experience in recent years gives an example for the political problems of increasing labour market flexibility: Although many of the underlying problems of German labour market had been well known by experts for years, the "Hartz reforms" have only been possible after a dramatic increase of unemployment. And even though these reforms are regarded to contribute to a falling unemployment (Franz, 2006), they remain politically contentious.

In recent years, the contrast between reform needs and observable reform activities - which is not confined to labour market policy - has attracted increasing academic attention. A first strand of the relevant literature explores survey data for typical differences between expert and lay perceptions of economic phenomena and also takes account of psychological insights (Baron and Kemp, 2004; Blendon et al., 1997; Caplan, 2002). A second literature is based on cross-country comparisons and scrutinizes the country or time specific factors which foster or block reforms (for a survey see chapter 4 in Heinemann et al., 2008). From the latter literature a specific insight emerges with respect to labour market reforms: Unlike reforms of financial market, product markets or foreign trade, no overall trend of market friendly reforms has been detected for labour markets in industrial countries over recent decades. On this field, regulation indicators often stay constant or even increase (Helbling et al., 2004). This persistence of regulation makes it desirable to widen our understanding for the individual factors which shape the support for interventionist labour market institutions and policies. Here our contribution comes in: Based on survey data we explore the drivers of labour market reform acceptance on the individual level.

Comparable studies have been undertaken for pension reforms (Boeri et al., 2002; Boeri and Tabellini, 2007) indicating that, besides self-interest, information and problem awareness is among the major driver of reform acceptance. An important point of reference is the literature on the political economy of labour market regulation starting with the insider-outsider-theory (Lindbeck and Snower, 1988) and advanced in recent years by contributions such as SaintPaul (2000), Boeri et al. (2004) and Neugart (2008). These authors are particularly interested to understand the relative political attractiveness of unemployment benefits versus 
employment protection, given that cross-country evidence indicates substitutability of generous unemployment benefits and rigid employment protection rules. Both Saint-Paul (2000) and Boeri et al. (2004) stress the importance of individual skill levels whereas Neugart (2008) draws the attention to the role of voters without labour market activity who depend on within household transfers.

While these labour economics approaches focus on self-interest as an explanation for sticky labour market institutions our approach allows for additional dimensions such as fairness preferences or the role of economic beliefs. Our results are based on the German General Social Survey “ALLBUS” which includes questions closely related to labour market policy preferences. These findings indicate that the wider perspective beyond mere self-interest has empirical substance. Although variables approximating self-interest play a crucial role, other dimensions contribute substantially to our understanding of individual heterogeneity in reform acceptance: Proxies for the degree of information, distributive preferences and beliefs on the sources of economic success prove significant. Furthermore, our results confirm that the divided history of Germany is important for understanding the heterogeneity of labour market policy preferences. Thus, the finding from Alesina and Fuchs-Schündeln (2007) that Germans socialized under communism show a stronger preference for state interventions holds for labour market policy.

The paper proceeds as follows: In section 2, we present the database and our indicators of labour market reform preferences. Section 3 is devoted to the identification of potential factors that explain why individuals differ in their views on labour market reforms. We present our econometric results (section 4) and present some policy conclusions in section 5.

\section{The database and its policy preference indicators}

The German General Social Survey “ALLBUS” has been conducted biannually since 1980 and is designed to be representative for the German population. ${ }^{1}$ Next to information on the respondents' assessment of several policies, ALLBUS offers data on the individual labour market status, socio-economic situation as well as on crucial economic beliefs and fairness preferences. In this study, we focus on data collected in the years 2000 and 2006. The latter wave is a particularly valuable source for the assessment of labour market policies as it

1 For details on ALLBUS see http://www.gesis.org/en/services/data/survey-data/allbus. 
contains questions defined in the context of the International Social Survey Programme (ISSP). The questions related to the ISSP's modules "Work Orientation III" and "Role of Government $I V$ " include items highly relevant for the acceptance of labour market reforms. ${ }^{2}$ Although the content of the year 2000 ALLBUS wave is less specific on labour markets, it is included since it offers questions on acceptance of social benefit cuts in general and on redistributive preferences.

This combined dataset contains the following items which function as our indicators for the individual preferences on labour market reforms and as dependent variables in the subsequent regressions. ${ }^{3}$ Two questions ask for the acceptance of benefit cuts: the one from the year 2000 wave refers to "social benefits" in general, whereas the 2006 wave focuses more specifically on the acceptance of cutting “unemployment benefits”. Preferences on the retirement age are captured by a wave 2006 question asking whether increasing the pension age is acceptable to solve the problems of the public pension system. Two further questions from the 2006 dataset are linked to the assessment of interventionist labour market policy, i.e. the support for "subsidies to declining industries" and "public employment programmes". Finally, one question from the later wave refers to employment protection and asks for the willingness to accept terminable contracts in order to avoid unemployment. It has to be stressed that this latter question is distinct from the others insofar as it does not ask for the assessment of a political approach but for individual behaviour. Lacking an alternative measure for the vividly debated point of employment protection, we include it in our analysis. However, analytical results based on this question must be interpreted with caution.

From the point of view of economic experts, the mentioned questions obviously lack precision. Survey respondents can have very different ideas on the particular design of "employment programmes" or "subsidies to declining industries". Also the questions on cutting (unemployment) benefits are far from precise with respect to the specificities of a reform which includes benefit cuts. In spite of these limitations, the answers nevertheless reveal the individual's tendency to support or reject market-oriented reforms which are based on a less generous welfare state, longer working years and less government interventions.

ALLBUS respondents participate either in the module "Work Orientation III" or "Role of Government $I V$ ”, thus data from both modules can only be used separately. This limitation precludes the construction of aggregate indicators or reform acceptance summarizing individual positions over all policy issues.

3 A detailed description of our variables is offered in Table 4 in the appendix. 
To facilitate the interpretation, all policy preference indicators have been recoded into binary variables that are equal to one if the respondent is in favour of liberal reform approaches (i.e. preferring a cut of benefits, accepting longer working years, supporting a cut of subsidies and employment programmes and accepting lower standards of employment protection) and zero otherwise.

\section{Table 1 about here}

The descriptive statistics (Table 1) of our policy preference indicators reveal that the opinions of (economic) experts are far from popular among the German population. The vast majority supports interventionist labour market policies and is sceptical on cutting benefits. The average acceptance of liberalising reforms ranges only between 16 (phasing out of employment programmes) and 27 percent (increasing the pension age). The only exception is the acceptance of terminable contracts which is supported by 72 percent. However, the mentioned character of the underlying survey question indicates that this supportive view reflects individual flexibility rather than policy preferences. Note that the rejection rates for cutting social benefits in the year 2000 wave and for cutting unemployment benefits in the year 2006 wave are almost the same. This is remarkable given that in between both years substantial labour market reforms have reduced the generosity of the system.

\section{Potential impact factors}

Very different factors may explain why individuals diverge in their views on labour market reforms. First, self-interest is likely to play a central role, since individuals are affected differently by reforms depending on their economic situation. Second, they have different levels of economically relevant information and entertain diverging economic beliefs, e.g., on the role of incentives. Both could lead them to different conclusions concerning the effectiveness of labour market reforms. Third, reforms may be judged from a fairness perspective with different ideas of fairness leading to different views on reforms. In this section, we discuss how different proxies for these three (and some other) factors should influence labour market reform acceptance. We pay particular attention to those six reform issues which are covered by the ALLBUS survey. 


\section{Self-interest}

The idea that self-interest drives both the support for and resistance against labour market reforms is the central creed of the political-economic view at labour market institutions. According to a highly influential view (Lindbeck and Snower, 1988), insiders (the employed) have an interest in labour market regulation shielding them against wage competition by outsiders (the unemployed). This theory can explain why democracies opt for employment protection even at the costs of raising structural unemployment as long as the median voter is an insider. Saint-Paul (2000) advances this basic idea further to explain the stability of rigid labour market institutions. He shows that unskilled workers may demand employment protection at the costs of skilled labour and the unemployed. Boeri et al. (2004) suggests that low skilled tend to favour employment protection relative to unemployment benefits and that this holds in particular for countries with a compressed wage structure. Neugart (2008) proposes that voters who are not part of the labour force and depend on transfers from a wage earner within their household are particularly supportive for employment protection (relative to unemployment benefits). These insights are helpful to identify individual characteristics which approximate self-interest in the formation of labour market policy preferences. ${ }^{4}$

The appropriate identification of self-interest will differ depending on which specific aspect of labour market institutions is at stake. With respect to the level of unemployment benefits we would clearly expect that unemployed or those with a particular exposure to job risk have an interest in a comfortable level. Employment risk is related to both job characteristics, e.g. private as opposed to public sector employment, and individual risk factors such as low qualification. Hence, all these factors should be negatively correlated with the support for reforms implying the cut in benefits.

Whereas the unemployed and the employed with a significant unemployment risk are united in their preference for high benefits, the insider-outsider theory predicts that both groups differ in their self-interest vis-à-vis measures which protect existing jobs. These measures are

Due to conceptual and data reasons our analytical approach is different to that of Boeri et al.

(2004) and Neugart (2008), who study the relative support of employment protection versus unemployment benefits. Conceptually, we are keen to understand the heterogeneity of views at a much wider range of labour market policy issues including active labour market policies. Apart from that, data limitations preclude a direct comparison of employment protection and unemployment benefit preferences for individuals since our preference proxies for these two reform dimensions originate from non-overlapping subsamples of the 2006 ALLBUS data (see Appendix, Table 4). 
not confined to installing employment protection rules but also include market interventions, e.g., through subsidies for declining industries. Because the unemployed do not benefit from this kind of initiatives, we expect support to be confined to those workers whose current job is at risk. Public employment programs are less exclusively targeted at job insiders. Therefore, they should be welcome by unemployed and employees alike as long as the latter's job is endangered. With respect to pension age, we expect unemployed or people with a significant risk of unemployment to oppose an increase in pension age since this prolongs the (potential) dependency on unemployment transfers.

For a number of reasons, the individual income shapes the self-interest in labour market reforms. First, income is a proxy for qualification which in turn signals job security since unemployment threatens workers with low qualification far above proportion. Second, with increasing income interventionist labour market policies lose their attraction because they become increasingly expensive from the individual perspective due to increasing contributions and taxes. Though unemployment benefits increase with former income in the German benefit system (at least up to the contribution ceiling), this effect does not outweigh the two factors named above. Hence, the higher the income the more likely it is that the individual is a net payer to the welfare state. Both effects imply the same sign prediction: High income individuals should be supportive for liberalisation and benefit cuts while opposing expensive subsidies or public employment programs. Due to the link between income and job security as well as between income and job satisfaction we expect high income individuals to support an increase of the pension age (which is indeed the fact for Italians and Germans, see Boeri et al., 2002).

Like income, age co-determines the self-interest in labour market reforms through a number of channels. First, older members of the workforce tend to face a lower chance of reemployment if they become unemployed. Thus, they should be more supportive of employment protection, high unemployment benefit, subsidies for declining industries and public employment programs. As people beyond pension age do not have a strong selfinterest in these issues, this impact of age can only be expected for respondents in working age. The impact of age on reform acceptance is more complicated when it comes to the issue of pension age. Current pensioners are expected to welcome the increase of the pension age since this stabilizes the level of current and future pension payments. The effect of age among people below retirement age largely depends on the speed with which the new pension age applies to different cohorts. In case of a sudden increase in the pension age for all cohorts, we expect the younger to be more supportive than the older employees because the former benefit 
from lower contribution rates while the latter would only have costs. Indeed, this is what Boeri et al. (2002) find on the basis of a survey conducted in Italy and Germany. Given that age is a proxy for the risk of unemployment, there is thus a double argument that older workers (as compared to both younger workers and pensioners) should be particularly opposed to an increase of pension age: The increase makes job loss more expensive and produces an unfavourable cost-benefit-balance for this age group. ${ }^{5}$

The ALLBUS database allows us to control for unemployment, the subjective judgement on the individual unemployment risk, employment in the public sector, respectively (see Table 4 for precise data definitions and sources). Beside income we also make use of an entrepreneur dummy since entrepreneurs are supposed to be net-contributors to the welfare state. In order to account for the possible non-linear relation between age and the acceptance of public pension reform, we introduce dummy-variables for three different age-groups (under 25, 25 to 45 and 45 to 65 years old) with the age-group above 65 being the point of reference.

\section{Information and economic beliefs}

Information has an impact in the context of economic policy and policy reform debates. In their analysis of Italian survey data, Boeri and Tabellini (2007) find that respondents who are more informed about the costs and functioning of the pension system are more willing to accept reforms. We expect a similar impact of information also in the context of marketoriented labour market reforms as well-informed and well-educated people should have at least a rough understanding of the functioning of labour markets.

Given that information is generally far from complete, we expect individuals to differ in their economic beliefs. With respect to labour market policies, the belief concerning the impact of incentives on economic effort and the belief concerning the impact of industriousness on economic outcomes are relevant (e.g., Alesina and Angeletos, 2005; Faravelli, 2007; Bischoff et al., 2008). The belief that individuals are responsible for their own economic situation should lead to a more favourable assessment of reforms targeted at fostering job search age 67 gradually: Only cohorts born after 1947 are affected at all and the final legal pension age of 67 only applies to those born 1964 or later. All cohorts in between expect an increase in pension age between 0 and 24 months. If survey respondents had this specific scheme in mind, this should increase the support of older workers who are hardly affected by the higher pension age. 
incentives such as cuts in employment benefits. Similarly, interventionist policies like subsidies for declining industries or employment programmes should be less popular among people who share these beliefs. In addition, the beliefs on economic self-responsibility should be correlated with an acceptance of a higher pension age.

We make use of two variables to proxy the respondents' degree of information about the consequences of labour market policy reforms in the ALLBUS dataset: First, we control for education achievements through a dummy for a university degree. Note that this variable is a combined factor approximating not only information but also income prospects and job market risk. Second, the participants' self-assessment concerning their degree of political information is used. The respondents' beliefs concerning the impact of effort and industriousness on economic success are captured as follows: A dummy-variable indicates that respondents believe that income differences increase the incentive for individual effort (ALLBUS 2000) and that "the future of the people in the East depends on their will to work" (ALLBUS 2006), respectively. For ALLBUS 2000 we also use respondents' belief that social background determines individual success.

\section{Fairness aspects}

Labour market policies are an integrative part of welfare state policies. Hence, preferences on redistribution are likely to partially shape the assessment of labour market reforms. An individual whose concept of fairness is dominated by the need principle (i.e. income distribution should reflect individual needs) will have different reform preferences than people whose concept of fairness is dominated by the equity principle (i.e. income distribution should reflect individual effort, see e.g., Fong, 2001, Konow, 2001; 2003). The first-named individual should be more supportive of high unemployment benefits, interventionist labour market approaches and less supportive of an increase in pension age. The opposite can be expected for persons following the equity principle.

Next to fairness preferences, beliefs on the procedural fairness of the political system may influence policy (reform) preferences. Following the concept of procedural fairness, the question of whether a certain outcome is considered fair crucially depends on the procedure through which it has been generated. Decisions are considered procedurally fair if every person potentially affected by them is given the chance to voice his opinion and concern. Neutrality demands that decision-makers are able to separate from self-interest. In addition, fair procedures have to be transparent and consistent (e.g., Anand, 2001; Dolan et al.; 2007). 
We do not have a clear sign prediction for the impact of the procedural beliefs on labour market reform acceptance because the perception of a fair political procedures could legitimize both the existing institutions (e.g., the current level of benefits) and its reforms (e.g., cutting these benefits).

ALLBUS 2000 offers the question whether the respondent prefers a distributive outcome that guarantees a "decent income even without achievement" which we use as a proxy for preferences for distributional fairness according to the need principle. The assessment whether politicians are interested in the problems of the common people is used as an indicator for the respondents' beliefs about procedural fairness (ALLBUS 2006). For ALLBUS 2000 we exploit information on the participants' beliefs concerning the functioning of the democratic system in Germany.

\section{Personal characteristics including socialisation under communism}

A number of personal characteristics are likely to go along with specific preferences for labour market reforms. Some of these personal characteristics capture specific aspects of selfinterest, information, beliefs or fairness assessments that cannot be observed directly. In addition, however, personal characteristics account for new aspects.

It is by now an established empirical fact that the history of communism has left its marks in behaviour and social preferences of Germans who were socialised under that regime. Alesina and Fuchs-Schündeln (2007) show that, compared to their Western German countrymen, Eastern Germans have a stronger preference for redistribution that cannot fully be explained by self-interest and the simple fact that Eastern Germans are relatively poor. Bischoff et al. (2008) show that Eastern Germans judge the existing social differences in their country to be less fair than their western fellow citizens. Following these insights a specific "GDR effect" may also have an impact on reform preferences even if our study design allows for the control of income or job risk. We thus expect that socialisation under Communism implies a stronger preference for interventionist labour market policies and welfare state generosity.

Religiosity is another personal characteristic of potential importance. Religious people are more likely to believe that it is one's duty to be industrious in the here and now (e.g., Benabou and Tirole, 2006; Tan, 2006). This may lead them to be sceptical on generous support for the unemployed or activist employment policies. On the other hand, they are likely to exhibit a stronger sensitivity for inequality and other social problems (e.g., Tan, 
2006). The net effect of religiosity on the assessment of labour market reforms is thus undetermined.

A complete research design has to take account of gender since the literature reports that women have a stronger preference for income redistribution be it through government policy or charity (e.g., Piper and Schnepf, 2008; Corneo and Gruener, 2002; Delaney and O’Toole, 2008). In addition, a gender gap is reported for beliefs (e.g., Schlesinger and Heldman, 2001; Fong, 2001), risk-aversion (e.g., Meier-Pesti and Penz, 2008) and the sensitivity to inequality (e.g., Schlesinger and Heldman, 2001): Compared to males, females are more risk-averse and more sensitive to inequality. Therefore, they should be more supportive for a generous unemployment support and interventionist labour market policies. No prediction is made for their preferences on an increasing pension age.

Based on the reasoning of Neugart (2008) on the role of intra-household transfers for the support of labour market regulation the household composition could matter for the reform readiness: The presumption is that households with members not active on the labour market are particularly interested into the job protection of the household's wage earner.

Again, the ALLBUS dataset offers useful indicators to control for the mentioned impact factors: The impact of socialisation under a communist regime is captured by a dummy which is equal to one if the respondent has either been born (ALLBUS 2000) or spent his youth in the former German Democratic Republic (ALLBUS 2006). Religiosity is assessed by membership in an institutionalized religious community. For the subset originating from the ISSP “Work Orientation III” module, a question on readiness to work even without needing the money is available as a proxy for intrinsic work motivation. Besides gender we also make use of the marital status and dummy for children to cover phenomena of within household transfer dependency. Finally, the individual's self-reported state of health is included which we expect to be of particular importance for the view on increasing the pension age. Table 2 summarises the signs of the expected effects on the different dimensions of labour market reform issues. 
Table 2: Expected signs

\begin{tabular}{|c|c|c|c|c|c|}
\hline & \multicolumn{5}{|c|}{ Support for (+) / resistance against (-) ... } \\
\hline & $\begin{array}{l}\text { Cutting } \\
\text { Unemployment } \\
\text { Benefits }\end{array}$ & $\begin{array}{l}\text { Increase of } \\
\text { pension age }\end{array}$ & $\begin{array}{ll}\text { Cutting } & \\
\text { subsidies } & \text { to } \\
\text { declining } & \\
\text { industries } & \end{array}$ & $\begin{array}{l}\text { Phasing out } \\
\text { employment } \\
\text { programmes }\end{array}$ & $\begin{array}{l}\text { Liberalising } \\
\text { employment } \\
\text { protection }\end{array}$ \\
\hline Unemployed & - & - & + & - & + \\
\hline Job risk & - & - & - & - & - \\
\hline Income & + & + & + & + & + \\
\hline Age* & - & - & - & - & - \\
\hline Information & + & + & + & + & + \\
\hline $\begin{array}{l}\text { Support for } \\
\text { need } \\
\text { principle of } \\
\text { distribution }\end{array}$ & - & - & - & - & - \\
\hline $\begin{array}{l}\text { Belief: self- } \\
\text { responsibility }\end{array}$ & + & + & + & + & + \\
\hline $\begin{array}{l}\text { Belief: } \\
\text { functioning } \\
\text { democracy }\end{array}$ & $?$ & $?$ & $?$ & $?$ & $?$ \\
\hline $\begin{array}{l}\text { Eastern } \\
\text { Germany }\end{array}$ & - & - & - & - & - \\
\hline Religious & ? & ? & ? & ? & $?$ \\
\hline Female & - & ? & - & - & - \\
\hline $\begin{array}{l}\text { Household } \\
\text { size }\end{array}$ & $?$ & ? & - & - & - \\
\hline
\end{tabular}

* Sign of expected age effect is limited to individuals in employment age.

\section{Econometric Results}

Table 3 displays the results of six probit regressions of our policy preference indicators on the set of explanatory variables as described above. We analyse the individual acceptance of reforms concerning preferences on benefits in regressions (1) and (2), pension age in (3), interventionist labour market policies in (4) and (5) and employment protection in (6). The slight differences in the inclusion of control variables are caused by the differing availability of indicators in the employed ALLBUS subsets or our theoretical reasoning as relating to the pension age (2) where differentiated age variables are used to allow for possible nonlinearities as discussed above. ${ }^{6}$

6 Furthermore, we allowed for general non-linearities for the variables age and income by including also a squared term. The results do not indicate a general non-linear relationship (obtainable from the authors). 
A first overall insight from the regressions is that individual labour market reform preferences are clearly shaped by self-interest. Among the self-interest proxy, income performs robustly in line with the theoretical expectations: A larger income is associated with a stronger support for market oriented reforms; only in the case of employment protection preferences the

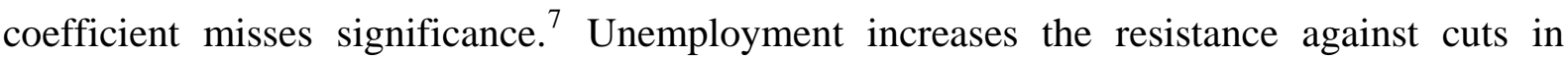
payments strongly with sizeable marginal effects. Similarly, we find the perception of a high unemployment risk to significantly foster the resistance against unemployment benefit cuts. These results indicate that pecuniary interests are a major impact factor for individual labour market reform preferences. We only find limited support for the insider-outsider-theory: As explained in section 2, the asymmetry of interests between insiders and outsiders should shine up in diverging preferences for subsidies to declining industries which benefit the protected employees but not the unemployed. Although the unemployment dummy has the expected sign in regression (4), it misses significance. ${ }^{8}$ Entrepreneurship has no significant impact, while public sector employment reveals the unexpected result of a stronger resistance against cuts of social benefits, cuts of subsidies and the increase of the pension age. While the latter results could be the consequence of higher pensions in the public sector which make late retirement even less attractive, the former may mirror bureaucratic self-interest into a large welfare state. Age has the expected negative and significant sign on the acceptance of cutting unemployment benefits and the liberalisation of employment protection. The non-linear effect of age on the views on a higher pension age is in line with expectations: The age groups between 25 and 65 are more critical of an increase than people in pension age (who are not hit by a higher pension age). In line with our considerations in section 2, we find no significant difference between the preferences of pensioners and respondents' younger than 25 as the latter should expect to gain from lower contributions during their working life. Note that our result with respect to the reform friendly younger generation is in line with those of Boeri et al. (2002) on the determinants of support for pension reforms.

The second essential overall result is that the determinants beyond pure self-interest contribute also to explain individual heterogeneity on labour market policy preferences and

\footnotetext{
$7 \quad$ To consider a possible impact of personal wealth we also included a dummy-variable equal to one for individuals living in a self-owned house or flat. Since this variable has found to be not significant, the results are not reported in this paper (obtainable from the authors).

Unfortunately the insider-outsider theory could not be tested for preferences on employment protection since data for this ALLBUS question is only available for employees.
} 
that their impact is substantial. Although our information proxies do not show the expected sign in all cases, the willingness of accepting market-friendly labour market reforms tends to be higher for well-informed and well-educated respondents. The self-reported degree of political awareness is connected with higher support for cutting subsidies to declining industries as well as the reduction of social benefits. A university degree raises the probability of supporting both an increase in pension age and the cut of subsidies substantially as can be seen from the high marginal effects (15.6 percentage points for the increase of pension age and 13.9 for the cut of subsidies preference). However, respondents with a university degree are less likely to support a phasing out of employment programmes.

Fairness preferences as well as beliefs on the role of individual effort for economic success emerge as further important determinants of the individual assessment of the welfare state: Being in favour of a distribution according to the need principle has a highly significant negative impact on the acceptance of benefit cuts which is the only regression where this particular variable has been available. The belief in individual self-responsibility is a major determinant for economic success. It consistently makes cuts of both social benefits in general and unemployment benefits in particular more acceptable. However and unexpectedly, this belief is also connected with less support for liberalised employment protection.

The beliefs concerning procedural fairness have no unidirectional impact on the reform preferences: On the one hand, we observe that individuals who trust politicians are more likely to accept a cut of subsidies to declining industries and a liberalisation of employment protection. On the other hand, the satisfaction with the democratic system leads also to resistance against lower social benefits. Note that we did not have a clear theoretical sign expectation in this case since the perception of procedural fairness may make both the status quo and its change more legitimate.

Among the other individual characteristics, the East dummy stands out: It provides strong support to our hypothesis that the socialisation in the former GDR has a lasting impact on individual labour market policy preferences. ${ }^{9}$ Since we control for self-interest related variables like age, unemployment or income, for economic beliefs and several socioeconomic factors, our east dummy isolates the particular impact of the past regime difference on policy preferences. The size of the GDR effects is large; the marginal effect reaches 10.0

9 The different economic performance of the Eastern and the Western part of Germany since reunification may reinforce the existence of systematically different attitudes toward labour market policies. 
percentage points for rejecting cuts in social benefits and even 12.2 percentage points for rejecting a higher pension age and is also sizable for the rejection to cuts in subsidies. Among the personal characteristics, poor health decreases the likeliness to support an increase of the pension age by approximately 8 percentage points, while intrinsic work motivation is related to an equally high probability of supporting this reform.

Finally, a gender gap exists for the assessment of cutting subsidies to declining industries and the liberalisation of employment protection. While women are more supportive for subsidies to declining industries they are more ready to accept a liberalised regime of employment protection. The latter result must be interpreted with attention to the specific question underlying the dependent variable in regression (6): Since this question targets more at individual labour market flexibility than at a policy position this gender gap could be related to different employment profiles of men and women on the German labour market.

Although they influence the assessment of specific policies in some cases, the remaining individual characteristics do not show a robust impact. Only in one case the religion dummy reach significance, indicating a particular support of religious respondents for declining industries. Marriage and children in the household only appear relevant for the assessment of a higher pension age.

\section{Table 3 about here}

\section{Conclusion}

Economists tend to explain labour market reform resistance by referring to purely rational approaches focusing, for example, on a pattern of reform winners and losers. Our results indicate that this approach has empirical substance and helps to understand individual assessments of different reform dimensions. For example, it is indeed the case that individuals who have high incomes, are young and possess a safe job are more inclined to favour cuts in unemployment benefits than those in less favourable circumstances. Nevertheless, selfinterest is not the full story behind the strong resistance against labour market reforms. Our results suggest that voters' positions are also influenced by their informative situation, by their beliefs on the sources of economic success or the functioning of democracy. In Germany, heterogeneity of views is also strongly increased by the split history of the country with Eastern Germans being more sceptical of liberal labour market reforms than their fellow nationals from the west even if individuals from both parts share a similar socio-economic 
profile. Our results point to one possible explanation why expert views on labour market differ so often from lay perceptions: resistance must not necessarily be expected from the reform losers only and it cannot be taken for granted that reform winners will be on the side of liberalising labour market reforms. Furthermore, our results may allow drawing lessons for a successfully selling market-oriented labour market reforms: It is not sufficient to point to the individual advantages of a reform. In addition, other sources of reform resistance need to be addressed. For example, evidence that individual labour market performance is a function of individual effort is helpful to foster reform acceptance and needs to be communicated.

Finally, our results are important for the possible impact of a macroeconomic shock on the acceptance of market-oriented labour market reforms. While the general reform literature is optimistic that crisis fosters the acceptance for reforms (Pitlik and Wirth, 2003), for labour market reforms less optimism is warranted. With a cyclical increase of unemployment an increasing number of voters is faced with the risk of dismissal and will, therefore, have an increasing interest in a comfortable level of unemployment benefits and protection or subsidies from a pure self-interest perspective. Beyond self-interest, a cyclical downturn caused by an external shock such as the global financial crisis has an additional reform impeding effect: The additional unemployment is the clear consequence of an external event not in the responsibility of employees. This in turn reduces the support for reforms which target at increasing individual effort, e.g., through stronger job search incentives. From these considerations we would forecast that the financial and economic crisis may have closed the window of opportunity for market oriented labour market reforms for the foreseeable future.

\section{References}

ALLBUS/ GGSS (2006), German General Social Survey Codebook 1980-2004 (ZA No.4243). Köln/ Mannheim.

Alesina, A. and Angelegos, G.-M. (2005), Fairness and Redistribution. American Economic Review 95: 961-980.

Alesina, A. and Fuchs-Schündeln, N. (2007), Good-Bye Lenin (or Not?): The Effect of Communism on People's Preferences. American Economic Review 97: 1507-1528.

Anand, P. (2001), Procedural Fairness in Economic and Social Choice: Evidence from a Survey of Voters. Journal of Economic Psychology 22: 247-270.

Baron, J. and Kemp, S. (2004), Support for Trade Restrictions, Attitudes, and Understanding of Comparative Advantage. Journal of Economic Psychology 25: 565-580.

Benabou, R. and Tirole, J. (2006), Beliefs in a Just World and Redistributive Politics. Quarterly Journal of Economics CXXI: 699-744. 
Bischoff, I., Heinemann, F. and Hennighausen, T. (2008), Individual Determinants of Social Fairness Assessment - The Case of Germany. ZEW Discussion Paper No. 08-063. Mannheim.

Blendon, R. J., Benson, J. M., Brodie, M., Morin, R., Altman, D. E., Gitterman, D., Brossard, M. and James, M. (1997), Bridging the Gap between the Public's and Economists' Views of the Economy. Journal of Economic Perspectives 11(3): 105-118.

Boeri, T., Börsch-Supan, A.H. and Tabellini, G. (2002), Pension Reforms and the Opinions of European Citizens. American Economic Review 92 (2): 396-401.

Boeri, T., Conde-Ruiz, J. I. and Galasso, V. (2004), Cross-Skill Redistribution and the Tradeoff between Unemployment Benefits and Employment Protection, IZA Discussion Paper No. 1371.

Boeri, T., and Tabellini, G. (2007), Does Information Increase Political Support for Pension Reform? Bocconi University and IGIER, mimeo.

Caplan, B. (2002), Systematically Biased Beliefs about Economics: Robust Evidence of Judgemental Anomalies from the Survey of Americans and Economists on the Economy. The Economic Journal 112(479): 1-26.

Corneo, G. and Gruener, H. P. (2002), Individual Preferences for Political Redistribution. Journal of Public Economics 83: 83-107.

Delaney, L. and O-Toole, F. (2008), Individual, Household and Gender Preferences for Social Transfers. Journal of Economic Psychology 29: 348-359.

Dolan, P., Edlin, R., Tsuchiya, A. and Wailoo, A. (2007), It Ain’t What You Do, It's How You Do It: Characteristics of Procedural Justice and Their Importance in Social Decision Making. Journal of Economic Behavior \& Organization 64: 157-170.

Faravelli, M. (2007), How Context Matters: A Survey Based Experiment on Distributive Justice. Journal of Public Economics 91: 1399-1422.

Fong, C. (2001), Social Preferences, Self-interest, and the Demand for Redistribution. Journal of Public Economics 82: 225-246.

Franz, W. (2006), Bewertung Hartz IV und Ein-Euro-Jobs durch den Sachverständigenrat. Zeitschrift für Wirtschaftspolitik 55(2): 177-181.

Heinemann, F., Förg, M., Frey, D., Jonas, E., Rotfuß, W., Traut-Mattausch, E. and Westerheide, P. (2008), Psychologie, Wachstum und Reformfähigkeit. Baden-Baden.

Helbling, T., Hakura, D. and Debrun, X. (2004), Fostering Structural Reforms in Industrial Countries. S. 103-146 in: International Monetary Fund (Hrsg.), World Economic Outlook 2004. Washington DC.

Konow, J. (2001), Fair and Square: The Four Sides of Distributive Justice. Journal or Economic Behavior and Organization 46: 137-164.

Konow, J. (2003), Which is the Fairest One of All? A Positive Analysis of Justice Theories. Journal of Economic Literature XLI: 1188-1239.

Lindbeck, A. and Snower, D.J. (1988), The Insider-Outsider Theory of Employment and Unemployment. Cambridge.

Meier-Pesti, K. and Penz, E. (2008), Sex or Gender? Expanding the Sex-based View by Introducing Masculinity and Feminity as Predictors of Financial Risk Taking. Journal of Economic Psychology 29: 180-196. 
Neugart, Michael (2008), The Choice of Insurance in the Labor Market. Public Choice 134: 445-462.

Piper, G. and Schnepf, S. V. (2008), Gender Differences in Charitable Giving in Great Britain. Voluntas 19: 103-124.

Pitlik, H. and Wirth, S. (2003), Do Crises Promote the Extent of Economic Liberalization?: An Empirical Test. European Journal of Political Economy 19: 565-581.

Saint-Paul, G. (2000), The Political Economy of Labour Market Institutions. Oxford.

Schlesinger, M. and Heldman, C. (2001), Gender Gap or Gender Gaps? New Perspective on Support for Government Action and Policies. Journal of Politics 63: 59-92.

Tan, J. H. W. (2006), Religion and Social Preferences: An experimental study. Economics Letters 90: 60-67.

Terwey, M., Bens, A., Baumann, H. and Baltzer, S. (2007), Datenhandbuch ALLBUS 2006 (ZA-Nr. 4500). Köln /Mannheim.

Table 1 Descriptive Statistics: Policy preference indicators

\begin{tabular}{|c|c|c|c|}
\hline Variable & Observations & Mean & $\begin{array}{l}\text { Standard } \\
\text { deviation }\end{array}$ \\
\hline \multicolumn{4}{|c|}{ ALLBUS 2000} \\
\hline Cutting social benefits & 2874 & 0.1764 & 0.3812 \\
\hline \multicolumn{4}{|c|}{ ALLBUS 2006} \\
\hline Cutting unemployment benefits & 1571 & 0.1808 & 0.3850 \\
\hline Increase of pension age & 1295 & 0.2672 & 0.4427 \\
\hline Cutting subsidies to declining industries & 1547 & 0.2217 & 0.4155 \\
\hline Phasing out employment programmes & 1549 & 0.1588 & 0.3656 \\
\hline Liberalising employment protection & 879 & 0.7224 & 0.4481 \\
\hline
\end{tabular}

Data definition and source see Appendix, Table 4. 
Table 3 Econometric Results

\begin{tabular}{|c|c|c|c|c|c|c|c|c|c|c|c|c|}
\hline & \multicolumn{2}{|c|}{$\begin{array}{c}(1) \\
\text { ALLBUS } 2000\end{array}$} & \multicolumn{2}{|c|}{$\begin{array}{c}(2) \\
\text { ALLBUS } 2006 \\
\text { Role of Government }\end{array}$} & \multicolumn{2}{|c|}{$\begin{array}{c}\text { (3) } \\
\text { ALLBUS } 2006 \\
\text { Work Orientation }\end{array}$} & \multicolumn{2}{|c|}{$\begin{array}{c}\text { (4) } \\
\text { ALLBUS } 2006 \\
\text { Role of Government }\end{array}$} & \multicolumn{2}{|c|}{$\begin{array}{c}\text { (5) } \\
\text { ALLBUS } 2006 \\
\text { Role of Government }\end{array}$} & \multicolumn{2}{|c|}{$\begin{array}{c}\text { (6) } \\
\text { ALLBUS } 2006 \\
\text { Work Orientation }\end{array}$} \\
\hline & \multicolumn{2}{|c|}{ Cutting social benefits } & \multicolumn{2}{|c|}{$\begin{array}{l}\text { Cutting unemployment } \\
\text { benefits }\end{array}$} & \multicolumn{2}{|c|}{ Increase of pension age } & \multicolumn{2}{|c|}{$\begin{array}{l}\text { Cutting subsidies to declining } \\
\text { industries }\end{array}$} & \multicolumn{2}{|c|}{$\begin{array}{l}\text { Phasing out employment } \\
\text { programmes }\end{array}$} & \multicolumn{2}{|c|}{$\begin{array}{l}\text { Liberalising employment } \\
\text { protection }\end{array}$} \\
\hline Variable & Coefficient & $\begin{array}{l}\text { Marginal } \\
\text { effect }\end{array}$ & Coefficient & $\begin{array}{l}\text { Marginal } \\
\text { effect }\end{array}$ & Coefficient & $\begin{array}{l}\text { Marginal } \\
\text { effect }\end{array}$ & Coefficient & $\begin{array}{l}\text { Marginal } \\
\text { effect }\end{array}$ & Coefficient & $\begin{array}{l}\text { Marginal } \\
\text { effect }\end{array}$ & Coefficient & $\begin{array}{c}\text { Marginal } \\
\text { effect }\end{array}$ \\
\hline \multicolumn{13}{|c|}{ Self-interest } \\
\hline AGE & $\begin{array}{l}-0.0002 \\
(-0.04)\end{array}$ & $\begin{array}{l}-0.00003 \\
{[0.0005]}\end{array}$ & $\begin{array}{c}-0.0137 \\
(-4.12)^{* * *}\end{array}$ & $\begin{array}{c}-0.0033 \\
{[-0.0569]}\end{array}$ & & & $\begin{array}{l}0.0051 \\
(1.54)\end{array}$ & $\begin{array}{c}0.0014 \\
{[0.0241]}\end{array}$ & $\begin{array}{l}0.0009 \\
(0.26)\end{array}$ & $\begin{array}{c}0.0002 \\
{[-0.0035]}\end{array}$ & $\begin{array}{l}-0.0133 \\
(-2.46)^{* *}\end{array}$ & $\begin{array}{c}-0.0044 \\
{[-0.0758]}\end{array}$ \\
\hline AGE 25 & & & & & $\begin{array}{c}-0.3093 \\
(-1.33)\end{array}$ & -0.0849 & & & & & & \\
\hline AGE 25-45 & & & & & $\begin{array}{c}-0.6188 \\
(-4.05)^{* * *}\end{array}$ & -0.1749 & & & & & & \\
\hline AGE 45-65 & & & & & $\begin{array}{c}-0.3943 \\
(-2.75)^{* * *}\end{array}$ & -0.1145 & & & & & & \\
\hline INCOME & $\begin{array}{c}0.0002 \\
(3.99)^{* * *}\end{array}$ & $\begin{array}{l}0.00005 \\
{[0.0436]}\end{array}$ & $\begin{array}{c}0.0002 \\
(3.66)^{* * *}\end{array}$ & $\begin{array}{l}0.00006 \\
{[0.0523]}\end{array}$ & $\begin{array}{c}0.0002 \\
(2.07)^{* *}\end{array}$ & $\begin{array}{c}0.00005 \\
{[0.0436]}\end{array}$ & $\begin{array}{c}0.0002 \\
(3.78)^{* * *}\end{array}$ & $\begin{array}{l}0.00007 \\
{[0.0611]}\end{array}$ & $\begin{array}{c}0.0002 \\
(3.26)^{* * *}\end{array}$ & $\begin{array}{l}0.00005 \\
{[0.0436]}\end{array}$ & $\begin{array}{c}-0.00007 \\
(-0.88)\end{array}$ & $\begin{array}{l}-0.00002 \\
{[-0.0175]}\end{array}$ \\
\hline INSECURE & $\begin{array}{c}-0.4920 \\
(-1.55)\end{array}$ & -0.0741 & $\begin{array}{c}-0.6082 \\
(-2.97)^{* * *}\end{array}$ & -0.1124 & $\begin{array}{l}-0.3148 \\
(-1.47)\end{array}$ & -0.0861 & $\begin{array}{r}-0.0394 \\
(-0.22)\end{array}$ & 0.0109 & $\begin{array}{r}-0.2792 \\
(-1.40)\end{array}$ & -0.0582 & $\begin{array}{l}0.2433 \\
(1.42)\end{array}$ & 0.0764 \\
\hline UNEMPLOYED & $\begin{array}{l}-0.5683 \\
(-2.03)^{* *}\end{array}$ & -0.0834 & $\begin{array}{l}-0.4959 \\
(-2.15)^{* *}\end{array}$ & -0.0962 & $\begin{array}{l}0.1875 \\
(0.92)\end{array}$ & 0.0602 & $\begin{array}{l}0.2941 \\
(1.60)\end{array}$ & 0.0909 & $\begin{array}{l}0.0319 \\
(0.16)\end{array}$ & 0.0076 & & \\
\hline $\begin{array}{l}\text { PUBLIC } \\
\text { SECTOR }\end{array}$ & $\begin{array}{c}-0.6634 \\
(-2.69)^{* * *}\end{array}$ & -0.0906 & $\begin{array}{c}-0.3140 \\
(-1.26)\end{array}$ & -0.0655 & $\begin{array}{l}-0.4688 \\
(-1.72)^{*}\end{array}$ & -0.1190 & $\begin{array}{l}-0.4692 \\
(-1.94)^{*}\end{array}$ & -0.1077 & $\begin{array}{c}-0.1264 \\
(-0.49)\end{array}$ & -0.0281 & $\begin{array}{l}-0.0680 \\
(-0.49)\end{array}$ & -0.0229 \\
\hline ENTREPRENEUR & $\begin{array}{l}0.2848 \\
(1.45)\end{array}$ & 0.0651 & $\begin{array}{l}-0.0768 \\
(-0.38)\end{array}$ & -0.0181 & $\begin{array}{l}0.1590 \\
(0.71)\end{array}$ & 0.0509 & $\begin{array}{l}0.1380 \\
(0.70)\end{array}$ & 0.0408 & $\begin{array}{l}0.0044 \\
(0.44)\end{array}$ & 0.0011 & & \\
\hline \multicolumn{13}{|c|}{ Information } \\
\hline UNIVERSITY & $\begin{array}{l}0.0225 \\
(0.15)\end{array}$ & 0.0045 & $\begin{array}{l}0.0140 \\
(0.10)\end{array}$ & 0.0034 & $\begin{array}{c}0.4645 \\
(3.22)^{* * *}\end{array}$ & 0.1561 & $\begin{array}{c}0.4411 \\
(3.38)^{* * *}\end{array}$ & 0.1387 & $\begin{array}{c}-0.3082 \\
(-2.04)^{* *}\end{array}$ & -0.0650 & $\begin{array}{l}0.2626 \\
(1.50)\end{array}$ & 0.0823 \\
\hline $\begin{array}{l}\text { POLITICALLY } \\
\text { INFORMED }\end{array}$ & $\begin{array}{l}0.1907 \\
(1.78)^{*}\end{array}$ & 0.0392 & $\begin{array}{l}-0.0132 \\
(-0.13)\end{array}$ & -0.0032 & $\begin{array}{l}0.0305 \\
(0.29)\end{array}$ & 0.0093 & $\begin{array}{c}0.3919 \\
(4.09)^{* * *}\end{array}$ & 0.1118 & $\begin{array}{l}0.1473 \\
(1.47)\end{array}$ & 0.0351 & $\begin{array}{l}-0.1827 \\
(-1.57)\end{array}$ & -0.0600 \\
\hline
\end{tabular}




\begin{tabular}{|c|c|c|c|c|c|c|c|c|c|c|c|c|}
\hline \multicolumn{13}{|c|}{ Fairness Preferences } \\
\hline NEED & $\begin{array}{c}-0.4279 \\
(-3.98)^{* * *}\end{array}$ & -0.0827 & & & & & & & & & & \\
\hline \multicolumn{13}{|c|}{ Beliefs } \\
\hline EFFORT & $\begin{array}{c}0.2533 \\
(2.39)^{* *}\end{array}$ & 0.0493 & $\begin{array}{c}0.3163 \\
(2.92)^{* * *}\end{array}$ & 0.0732 & $\begin{array}{l}0.0053 \\
(0.05)\end{array}$ & 0.0016 & $\begin{array}{l}0.0861 \\
(0.85)\end{array}$ & 0.0240 & $\begin{array}{l}0.1250 \\
(1.18)\end{array}$ & 0.0290 & $\begin{array}{l}-0.2220 \\
(-1.83)^{*}\end{array}$ & -0.0722 \\
\hline BACKGROUND & $\begin{array}{l}-0.1600 \\
(-1.55)\end{array}$ & -0.0325 & & & & & & & & & & \\
\hline $\begin{array}{l}\text { PROCEDURAL } \\
\text { FAIRNESS }\end{array}$ & $\begin{array}{l}-0.2109 \\
(-1.78)^{*}\end{array}$ & -0.0443 & $\begin{array}{l}0.0823 \\
(0.68)\end{array}$ & 0.0205 & $\begin{array}{c}-0.0815 \\
(-0.61)\end{array}$ & -0.0243 & $\begin{array}{c}0.3996 \\
(3.39)^{* * *}\end{array}$ & 0.1237 & $\begin{array}{l}0.1259 \\
(1.00)\end{array}$ & 0.0310 & $\begin{array}{c}0.3138 \\
(2.04)^{* *}\end{array}$ & 0.0976 \\
\hline \multicolumn{13}{|c|}{ Other } \\
\hline SICK & & & & & $\begin{array}{l}-0.2856 \\
(-1.84)^{*}\end{array}$ & -0.0804 & & & & & & \\
\hline EAST & $\begin{array}{l}-0.5340 \\
(-3.88)^{* * *}\end{array}$ & -0.0998 & $\begin{array}{l}-0.1955 \\
(-1.54)\end{array}$ & -0.0468 & $\begin{array}{c}-0.4137 \\
(-3.32)^{* * *}\end{array}$ & -0.1224 & $\begin{array}{l}-0.2232 \\
(-1.79)^{*}\end{array}$ & -0.0618 & $\begin{array}{l}-0.0253 \\
(-0.20)\end{array}$ & -0.0060 & $\begin{array}{l}-0.0213 \\
(-0.15)\end{array}$ & -0.0071 \\
\hline RELIGION & $\begin{array}{l}0.2029 \\
(1.48)\end{array}$ & 0.0389 & $\begin{array}{l}0.0733 \\
(0.60)\end{array}$ & 0.0177 & $\begin{array}{l}-0.1795 \\
(-1.52)\end{array}$ & -0.0552 & $\begin{array}{l}-0.4824 \\
(-4.14)^{* * *}\end{array}$ & -0.1412 & $\begin{array}{l}-0.0505 \\
(-0.42)\end{array}$ & -0.0120 & $\begin{array}{l}-0.0981 \\
(-0.72)\end{array}$ & -0.0323 \\
\hline FEMALE & $\begin{array}{l}-0.0078 \\
(-0.07)\end{array}$ & -0.0016 & $\begin{array}{l}0.0324 \\
(0.31)\end{array}$ & 0.0079 & $\begin{array}{l}0.0428 \\
(0.39)\end{array}$ & 0.0130 & $\begin{array}{l}-0.1393 \\
(-1.38)^{*}\end{array}$ & -0.0391 & $\begin{array}{l}-0.1068 \\
(-1.01)\end{array}$ & -0.0252 & $\begin{array}{l}0.2948 \\
(2.33)^{* *}\end{array}$ & 0.0974 \\
\hline MARRIED & $\begin{array}{l}0.0211 \\
(0.17)\end{array}$ & 0.0042 & $\begin{array}{l}0.0116 \\
(0.10)\end{array}$ & 0.0028 & $\begin{array}{l}0.2309 \\
(1.93)^{*}\end{array}$ & 0.0696 & $\begin{array}{l}0.0004 \\
(0.00)\end{array}$ & 0.0001 & $\begin{array}{l}0.0985 \\
(0.84)\end{array}$ & 0.0231 & $\begin{array}{l}-0.0011 \\
(-0.01)\end{array}$ & -0.0004 \\
\hline CHILDREN & $\begin{array}{l}0.0372 \\
(0.26)\end{array}$ & 0.0073 & $\begin{array}{c}-0.0622 \\
(-0.49)\end{array}$ & -0.0153 & $\begin{array}{l}-0.2505 \\
(-1.93)^{*}\end{array}$ & -0.0791 & $\begin{array}{l}-0.0227 \\
(-0.18)\end{array}$ & -0.0064 & $\begin{array}{l}-0.2005 \\
(-1.57)\end{array}$ & -0.0493 & $\begin{array}{l}-0.0466 \\
(-0.32)\end{array}$ & -0.0007 \\
\hline $\begin{array}{l}\text { INTRINSIC WORK } \\
\text { MOTIVATION }\end{array}$ & & & & & $\begin{array}{c}0.3104 \\
(2.68)^{* * *}\end{array}$ & 0.0898 & & & & & $\begin{array}{l}0.0775 \\
(0.61)\end{array}$ & 0.0261 \\
\hline \multicolumn{13}{|l|}{ Regression diagnostic } \\
\hline $\begin{array}{l}\text { p-value joint significance } \\
\text { of variables }\end{array}$ & 0.0000 & & 0.0000 & & 0.0000 & & 0.0000 & & 0.0037 & & 0.0003 & \\
\hline Observations & 1093 & & 1021 & & 824 & & 1017 & & 1015 & & 617 & \\
\hline Pseudo-R ${ }^{2}$ & 0.1412 & & 0.0833 & & 0.0854 & & 0.1286 & & 0.0376 & & 0.0535 & \\
\hline
\end{tabular}

$* / * * / * * *$ significant at the 10/5/1 percent level. The effect of an increase of the variables AGE and INCOME by one standard deviation (2006 wave) is presented in the square brackets. 
Appendix, Table 4 Variable definitions

\begin{tabular}{|c|c|c|c|c|}
\hline Variable & Unit & Explanation & Categories & $\begin{array}{l}\text { ALLBUS } \\
\text { code* }\end{array}$ \\
\hline \multicolumn{5}{|c|}{ Policy preference indicator } \\
\hline $\begin{array}{l}\text { Cutting social } \\
\text { benefits }\end{array}$ & Dummy & Cut of social benefits. & $\begin{array}{l}1 \text {, if the respondent approves, } \\
0 \text { otherwise. }\end{array}$ & $\mathrm{v} 158^{\mathrm{a}}$ \\
\hline $\begin{array}{l}\text { Cutting } \\
\text { unemployment } \\
\text { benefits }\end{array}$ & Dummy & Cut of unemployment benefits. & $\begin{array}{l}1 \text {, if the respondent approves, } \\
0 \text { otherwise. }\end{array}$ & $\mathrm{v} 641^{\mathrm{b}}$ \\
\hline $\begin{array}{l}\text { Increase of pension } \\
\text { age }\end{array}$ & Dummy & $\begin{array}{l}\text { Increase of pension age in order to } \\
\text { solve the problems of the public } \\
\text { pension system. }\end{array}$ & $\begin{array}{l}1 \text {, if the respondent approves, } \\
0 \text { otherwise. }\end{array}$ & $\mathrm{v} 605^{\mathrm{c}}$ \\
\hline $\begin{array}{l}\text { Cutting subsidies to } \\
\text { declining industries }\end{array}$ & Dummy & $\begin{array}{l}\text { Cut of subsidies to declining } \\
\text { industries. }\end{array}$ & $\begin{array}{l}1 \text {, if the respondent approves, } \\
0 \text { otherwise. }\end{array}$ & v633 \\
\hline $\begin{array}{l}\text { Phasing out } \\
\text { employment } \\
\text { programmes }\end{array}$ & Dummy & $\begin{array}{l}\text { Cut financing of public } \\
\text { employment programs. }\end{array}$ & $\begin{array}{l}1 \text {, if the respondent approves, } \\
0 \text { otherwise. }\end{array}$ & v630 \\
\hline $\begin{array}{l}\text { Liberalising } \\
\text { employment } \\
\text { protection }\end{array}$ & Dummy & $\begin{array}{l}\text { Liberalization of employment } \\
\text { protection in order to avoid } \\
\text { unemployment. }\end{array}$ & $\begin{array}{l}\text { 1, if the respondent would } \\
\text { accept a terminable working } \\
\text { contract, } 0 \text { otherwise. }\end{array}$ & $\mathrm{v} 587^{\mathrm{c}}$ \\
\hline \multicolumn{5}{|c|}{ Self-interest } \\
\hline AGE & $\begin{array}{l}\text { Discrete } \\
\text { variable }\end{array}$ & Age of the respondent. & $18-95\left(94^{\mathrm{b}, \mathrm{c}}\right)$ & $\begin{array}{l}\mathrm{v} 432^{\mathrm{a}} \\
\mathrm{v} 27^{\mathrm{b}, \mathrm{c}}\end{array}$ \\
\hline AGE 25 & Dummy & Younger than 25 years. & $\begin{array}{l}1 \text {, for respondents aged } 18 \text { to } \\
24,0 \text { otherwise. }\end{array}$ & $\mathrm{v} 27^{\mathrm{c}}$ \\
\hline AGE $25-45$ & Dummy & Between 25 and 45 years old. & $\begin{array}{l}\text { 1, for respondents aged } 25 \text { to } \\
45,0 \text { otherwise. }\end{array}$ & $\mathrm{v} 27^{\mathrm{c}}$ \\
\hline AGE $45-65$ & Dummy & Between 45 and 65 years old. & $\begin{array}{l}1 \text {, for respondents aged } 45 \text { to } \\
65,0 \text { otherwise. }\end{array}$ & $\mathrm{v} 27^{\mathrm{c}}$ \\
\hline INCOME & $\begin{array}{l}\text { Continuous } \\
\text { variable }\end{array}$ & $\begin{array}{l}\text { Monthly net income of the } \\
\text { respondent (in EURO). }^{1}\end{array}$ & $0-12500\left(8000^{\mathrm{b}, \mathrm{c}}\right)$ & $\begin{array}{l}\mathrm{v} 579^{\mathrm{a}}, \\
\mathrm{v} 381^{\mathrm{b}, \mathrm{c}}\end{array}$ \\
\hline
\end{tabular}




\begin{tabular}{|c|c|c|c|c|}
\hline INSECURE & Dummy & Job insecurity of the respondent. & $\begin{array}{l}\text { 1, if the respondent is afraid of } \\
\text { becoming unemployed, } 0 \\
\text { otherwise. }\end{array}$ & $\begin{array}{l}\mathrm{v} 481^{\mathrm{a}}, \\
\mathrm{v} 210^{\mathrm{b}, \mathrm{c}}\end{array}$ \\
\hline UNEMPLOYED & Dummy & Employment status of the respondent. & $\begin{array}{l}\text { 1, if the respondent is currently } \\
\text { unemployed, } 0 \text { otherwise. }\end{array}$ & $\begin{array}{l}\mathrm{v} 462^{\mathrm{a}}, \\
\mathrm{v} 217^{\mathrm{b}, \mathrm{c}}\end{array}$ \\
\hline \multirow[t]{2}{*}{ PUBLIC SECTOR } & Dummy & $\begin{array}{l}\text { Occupational position of the } \\
\text { respondent: Civil servant. }\end{array}$ & $\begin{array}{l}\text { 1, if the respondent is a civil } \\
\text { servant, } 0 \text { otherwise. }\end{array}$ & $\begin{array}{l}\mathrm{v} 463^{\mathrm{a}}, \\
\mathrm{v} 189^{\mathrm{b}, \mathrm{c}}\end{array}$ \\
\hline & Dummy & Employment in the public sector. & $\begin{array}{l}\text { 1, if the respondent is employed in } \\
\text { the public sector, } 0 \text { otherwise. }\end{array}$ & v206 ${ }^{\mathrm{c}}$ \\
\hline ENTREPRENEUR & Dummy & $\begin{array}{l}\text { Occupational position of the } \\
\text { respondent: Entrepreneur or } \\
\text { Independent Professional. }\end{array}$ & $\begin{array}{l}\text { 1, if the respondent is self- } \\
\text { employed, } 0 \text { otherwise. }\end{array}$ & $\begin{array}{l}\mathrm{v} 463^{\mathrm{a}}, \\
\mathrm{v} 189^{\mathrm{b}, \mathrm{c}}\end{array}$ \\
\hline \multicolumn{5}{|c|}{ Information } \\
\hline UNIVERSITY & Dummy & Respondent’s educational level. & $\begin{array}{l}\text { 1, if the respondent has a } \\
\text { university (for applied science) } \\
\text { degree, } 0 \text { otherwise. }\end{array}$ & $\begin{array}{l}\text { v457, } \\
\text { v458 } \\
\text { v184, } \\
\text { v185,c }\end{array}$ \\
\hline \multirow[t]{3}{*}{$\begin{array}{l}\text { POLITICALLY } \\
\text { INFORMED }\end{array}$} & Dummy & Political interest of the respondent. & $\begin{array}{l}\text { 1, if the respondent is (very) } \\
\text { strongly interested in politics, } 0 \\
\text { otherwise. }\end{array}$ & $\mathrm{v} 20^{\mathrm{a}}$ \\
\hline & Dummy & $\begin{array}{l}\text { The respondent is informed about the } \\
\text { major political problems in Germany. }\end{array}$ & $\begin{array}{l}\text { 1, if the respondent is informed, } 0 \\
\text { otherwise. }\end{array}$ & $\mathrm{v} 665^{\mathrm{b}}$ \\
\hline & Dummy & $\begin{array}{l}\text { Respondent collects information } \\
\text { about candidates before an election. }\end{array}$ & $\begin{array}{l}\text { 1, if the respondent informs } \\
\text { himself, } 0 \text { otherwise. }\end{array}$ & $\mathrm{v} 54^{\mathrm{C}}$ \\
\hline \multicolumn{5}{|c|}{ Fairness preferences } \\
\hline NEED & Dummy & $\begin{array}{l}\text { Decent income even without } \\
\text { achievement. }\end{array}$ & $\begin{array}{l}1 \text {, if the respondent approves, } 0 \\
\text { otherwise. }\end{array}$ & $\mathrm{v} 152^{\mathrm{a}}$ \\
\hline \multicolumn{5}{|c|}{ Beliefs } \\
\hline \multirow[t]{2}{*}{ EFFORT } & Dummy & $\begin{array}{l}\text { Income differences increase the } \\
\text { incentive for individual effort. }\end{array}$ & $\begin{array}{l}1 \text {, if respondent approves, } 0 \\
\text { otherwise. }\end{array}$ & $\mathrm{v} 153^{\mathrm{a}}$ \\
\hline & Dummy & $\begin{array}{l}\text { Future of the people in the East } \\
\text { depends on the will to work. }\end{array}$ & $\begin{array}{l}\text { 1, if the respondent approves, } 0 \\
\text { otherwise. }\end{array}$ & $\mathrm{v} 495^{\mathrm{b}, \mathrm{c}}$ \\
\hline BACKGROUND & Dummy & $\begin{array}{l}\text { Prerequisites for social success } \\
\text { and upward mobility: Right social } \\
\text { background. }\end{array}$ & $\begin{array}{l}\text { 1, if the respondent approves, } 0 \\
\text { otherwise. }\end{array}$ & $\mathrm{v} 145^{\mathrm{a}}$ \\
\hline
\end{tabular}




\begin{tabular}{|c|c|c|c|c|}
\hline \multirow[t]{2}{*}{$\begin{array}{l}\text { PROCEDURAL } \\
\text { FAIRNESS }\end{array}$} & Dummy & $\begin{array}{l}\text { Satisfaction with democracy in } \\
\text { the FRG. }\end{array}$ & $\begin{array}{l}\text { 1, if the respondent approves, } 0 \\
\text { otherwise. }\end{array}$ & $\mathrm{v} 17^{\mathrm{a}}$ \\
\hline & Dummy & $\begin{array}{l}\text { Politicians are interested in } \\
\text { problems of common people. }\end{array}$ & $\begin{array}{l}\text { 1, if the respondent approves, } 0 \\
\text { otherwise. }\end{array}$ & $\mathrm{v} 10^{\mathrm{b}, \mathrm{c}}$ \\
\hline \multicolumn{5}{|c|}{ Other } \\
\hline \multirow[t]{2}{*}{ EAST } & Dummy & Origin of the respondent. & $\begin{array}{l}\text { 1, if the respondent is born in the } \\
\text { former GDR, } 0 \text { otherwise. }\end{array}$ & $\mathrm{v} 874^{\mathrm{a}}$ \\
\hline & Dummy & $\begin{array}{l}\text { State in which the respondent } \\
\text { spent his/her youth. }\end{array}$ & $\begin{array}{l}\text { 1, if the respondent spent his/her } \\
\text { youth in the former GDR, } 0 \\
\text { otherwise. }\end{array}$ & $\mathrm{v} 37^{\mathrm{b}, \mathrm{c}}$ \\
\hline RELIGION & Dummy & $\begin{array}{l}\text { Religious denomination of the } \\
\text { respondent. }\end{array}$ & $\begin{array}{l}\text { 1, if the respondent belongs to an } \\
\text { institutionalized religious } \\
\text { community, } 0 \text { otherwise. }\end{array}$ & $\begin{array}{l}\mathrm{v} 435^{\mathrm{a}}, \\
\mathrm{v} 500^{\mathrm{b}, \mathrm{c}}\end{array}$ \\
\hline FEMALE & Dummy & Sex of the respondent. & $\begin{array}{l}\text { 1, if the respondent is female, } 0 \\
\text { otherwise. }\end{array}$ & $\begin{array}{l}\mathrm{v} 434^{\mathrm{a}}, \\
\mathrm{v} 174^{\mathrm{b}, \mathrm{c}}\end{array}$ \\
\hline MARRIED & Dummy & Marital Status of the respondent. & $\begin{array}{l}1 \text {, if the respondent is married, } 0 \\
\text { otherwise. }\end{array}$ & $\begin{array}{l}\mathrm{v} 608^{\mathrm{a}}, \\
\mathrm{v} 242^{\mathrm{b}, \mathrm{c}}\end{array}$ \\
\hline CHILDREN & Dummy & Children of the respondent. & $\begin{array}{l}\text { 1, if the respondent has own children, } \\
0 \text { otherwise. }\end{array}$ & $\begin{array}{l}\mathrm{v} 997^{\mathrm{a}} \\
\mathrm{v} 443^{\mathrm{b}, \mathrm{c}}\end{array}$ \\
\hline $\begin{array}{l}\text { INTRINSIC WORK } \\
\text { MOTIVATION }\end{array}$ & Dummy & $\begin{array}{l}\text { Work although I do not need the } \\
\text { money. }\end{array}$ & $\begin{array}{l}\text { 1, if the respondent approves, } 0 \\
\text { otherwise. }\end{array}$ & v536 \\
\hline SICK & Dummy & Respondent's state of health. & $\begin{array}{l}\text { 1, if the respondent is not (very) } \\
\text { healthy, } 0 \text { otherwise. }\end{array}$ & $\mathrm{v} 241^{\mathrm{b}, \mathrm{c}}$ \\
\hline
\end{tabular}

* The codes referring to questions from 2006 ALLBUS are taken from the German Codebook (see Terwey et al., 2007), while those for the 2000 wave are from the German General Social Survey Codebook 1980-2004.

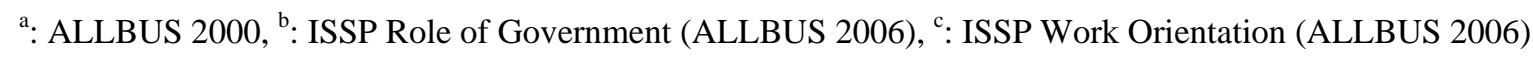

